\title{
Improved Thematic Learning Outcomes of My Daily Task Sub-Themes at School Using Concrete Media for Class II Students of SDN 3 Pengadegan Wangon
}

\section{Hasan Dwi Nugroho}

SDN 3 Pengadegan

hasandwinugroho@gmail.com

Article History

accepted 01/11/2020

\begin{abstract}
The purpose of this research is to improve the thematic learning outcomes of my daily tasks at school by using concrete media. This research is a classroom action research (PTK) which is carried out in three cycles consisting of planning, implementing, observing and reflecting. The subjects of this study were students of class II SDN 3 Pengadegan Banyumas in the 2020/2021 school year, totaling 20 students. Data collection techniques using tests. Data analysis includes data reduction, data presentation, and drawing conclusions. Research shows that the application of concrete media is very significant in improving student learning outcomes in class II SDN 3 Pengadegan, Wangon District, Banyumas Regency in the academic year 2020/2021 as evidenced by the completeness of learning outcomes $100 \%$ with an average value of 98 in cycle III.
\end{abstract}

Keywords: Students, Concrete Media, Learning Outcomes

\begin{abstract}
Abstrak
Tujuan penelitian ini adalah untuk meningkatkan hasil belajar pembelajaran tematik subtema Tugasku sehari-hari di Sekolah dengan menggunakan media konkret. Penelitian ini merupakan penelitian tindakan kelas (PTK) yang dilaksanakan dalam tiga siklus terdiri dari tahap perencanaan, pelaksanaan, observasi dan refleksi. Subjek penelitian ini adalah peserta didik kelas II SDN 3 Pengadegan Banyumas tahun pelajaran 2020/2021 yang berjumlah 20 peserta didik. Teknik pengumpulan data dengan menggunakan tes. Analisis data meliputi reduksi data, penyajian data, dan penarikan kesimpulan. Penelitian menunjukkan bahwa penerapan media konkret sangat signifikan dalam meningkatkan hasil belajar siswa di kelas II SDN 3 Pengadegan Kecamatan Wangon Kabupaten Banyumas tahun pelajaran 2020/2021 yang dibuktikan dengan ketuntasan hasil belajar 100\% dengan nilai rata-rata 98 pada siklus III.
\end{abstract}

Kata kunci: Siswa, Media Konkret, Hasil Belajar

Social, Humanities, and Education Studies (SHEs): Conference Series https://jurnal.uns.ac.id/shes 


\section{PENDAHULUAN}

Pendidikan adalah aspek yang sangat penting dalam menunjang kemajuan bangsa di masa depan. Melalui pendidikan, manusia sebagai subjek pembangunan dapat dididik, dibina dan dikembangkan potensi-potensinya. Hal tersebut sejalan dengan isi tujuan pendidikan nasional yang tertuang dalam Undang-undang Republik Indonesia Nomor 20 Tahun 2003 tentang Sistem Pendidikan Nasional menyebutkan, bahwa pendidikan nasional berfungsi mengembangkan kemampuan dan membentuk watak serta peradaban bangsa yang bermartabat dalam rangka mencerdaskan kehidupan bangsa. Pendidikan bertujuan untuk mengembangkan potensi peserta didik agar menjadi manusia yang beriman, berilmu, cakap, kreatif, mandiri, dan menjadi warga Negara yang demokratis serta bertanggung jawab. Melaui pendidikan inilah tercipta guru-guru profesional dan siswa-siswa yang menjadi penerus bangsa di masa yang akan datang.

Guru dalam mengajar seharusnya memiliki kemampuan merancang strategi mengajar, memilih metode sesuai dengan karakter anak, dan menggunakan media yang tepat sehingga siswa mengikuti proses pembelajaran secara aktif, kreatif, dan menyenangkan. Dengan demikian materi yang disajikan dapat diterima oleh siswa dengan mudah dan tidak menimbulkan verbalisme. Disamping itu juga guru harus mampu menilai kinerjanya sendiri. Seberapa banyak materi yang disampaikan dapat diserap oleh anak, dan seberapa besar potensi anak dapat tergali dalam proses pembelajaran, sehingga prestasi yang dicapai oleh anak benar-benar maksimal. Hal itu kiranya yang menjadi harapan orang tua murid, sekolah, maupun guru itu sendiri.

Dalam kenyataan di lapangan sering tidak demikian. Guru melaksanakan pembelajaran hanya sebagai tugas rutin harian saja. Guru masuk ke kelas langsung menyampaikan materi pelajaran dengan persiapan seadanya sehingga respon siswa tidak seperti yang diharapkan. Ketika guru sedang menjelaskan pelajaran ada beberapa siswa yang asyik bercerita, ada yang bermain sendiri, ada yang diam tapi ditanya tidak bisa menjawab, bahkan kadang ada yang mengantuk. Di akhir pembelajaran pada tes formatif setelah dikoreksi hasilnya rata-rata masih di bawah KKM. Ini berarti yang mencapai ketuntasan belajar masih di bawah standar.

Menyadari keadaan tersebut, dengan berbekal kejujuran dan keterbukaan saya mencoba melakukan diagnosa terhadap pembelajaran yang telah dilakukan, kemudian mencoba melakukan perbaikan melalui Penelitian Tindakan Kelas (PTK) di tempat peneliti bertugas.

Proses perbaikan pembelajaran diawali dengan melakukan identifikasi masalah. Berdasarkan fakta di atas, saya meminta bantuan supervisor dan teman sejawat untuk membantu mengidentifikasi kekurangan dari pembelajaran yang telah dilakukan. Dari diskusi terhadap beberapa masalah yang terjadi dalam pembelajaran, yaitu nilai hasil belajar siswa masih rendah, siswa kurang aktif dalam mengikuti pembelajaran, dan Minat belajar siswa rendah

Untuk mengetahui penyebab timbulnya masalah tersebut, perlu dilakukan analisis. Berdasarkan hasil refleksi diri, kajian beberapa dokumen, diskusi dengan teman sejawat, dan bertanya kepada kepala sekolah, diprediksi faktor penyebab rendahnya tingkat pemahaman dan minat belajar siswa terhadap materi yang diajarkan antara lain : media yang digunakan guru tidak menarik, guru kurang mampu menciptakan kondisi pembelajaran yang membangkitkan minat belajar siswa sehingga siswa mendapatkan nilai hasil belajar yang maksimal dan signifikan pada materi tematik subtema tugasku sehari-hari di sekolah.

Dengan mempertimbangkan kedua faktor penyebab di atas alternatif pemecahan masalah yang akan ditempuh diorientasikan pada penggunaan media mengajar yaitu dengan menggunakan media konkret. Berdasarkan latar belakang tersebut penulis mengambil Judul Karya IImiah yaitu : "Peningkatan Hasil Belajar 
Pembelajaran Tematik Subtema Tugasku Sehari-Hari Di Sekolah Menggunakan Media Konkret Pada Siswa Kelas II SDN 3 Pengadegan Wangon".

\section{METODE}

Penelitian ini merupakan penelitian tindakan kelas (PTK) yang dilaksanakan dalam tiga siklus. Setiap siklus terdiri dari tahap perencanaan, pelaksanaan, observasi, dan refleksi. Subjek penelitian ini adalah peserta didik kelas II SDN 3 Pengadegan Kabupaten Banyumas tahun pelajaran 2020/2021 yang berjumlah 20 peserta didik.

Data yang dianalisis berupa data kuantitatif yaitu hasil belajar peserta didik tema tugasku sehari-hari di sekolah. Teknik pengumpulan data menggunakan tes.. Analisis data meliputi reduksi data, penyajian data, dan penarikan kesimpulan.

\section{HASIL DAN PEMBAHASAN}

Berdasarkan analisis hasil penelitian yang telah diuraikan maka pembahasan pada penelitian ini sebagai berikut:

Tabel 1. Rekapitulasi Ketuntasan Belajar Siswa

\begin{tabular}{|c|c|c|c|c|c|c|}
\hline \multirow[b]{2}{*}{ No } & \multirow[b]{2}{*}{ Pembelajaran } & \multicolumn{5}{|c|}{ Hasil Belajar Siswa } \\
\hline & & Tuntas & Persentase & Belum & Persentase & $\begin{array}{l}\text { Nilai } \\
\text { rata- } \\
\text { rata }\end{array}$ \\
\hline \multicolumn{7}{|c|}{ Bahasa Indonesia } \\
\hline 1 & Studi Awal & 7 & 35 & 13 & 65 & 65 \\
\hline 2 & Siklus I & 16 & 80 & 4 & 20 & 82 \\
\hline 3 & Siklus II & 20 & 100 & 0 & 0 & 87 \\
\hline 4 & Siklus III & 20 & 100 & 0 & 0 & 98 \\
\hline \multicolumn{7}{|c|}{ PPKn } \\
\hline 1 & Studi Awal & 8 & 40 & 12 & 60 & 67 \\
\hline 2 & Siklus I & 14 & 70 & 6 & 30 & 70 \\
\hline 3 & Siklus II & 20 & 100 & 0 & 0 & 88 \\
\hline 4 & Siklus III & 20 & 100 & 0 & 0 & 98 \\
\hline \multicolumn{7}{|c|}{ Matematika } \\
\hline 1 & Studi Awal & 9 & 45 & 13 & 65 & 63 \\
\hline 2 & Siklus I & 13 & 65 & 7 & 35 & 75 \\
\hline 3 & Siklus II & 20 & 100 & 0 & 0 & 85 \\
\hline 4 & Siklus III & 20 & 100 & 0 & 0 & 98 \\
\hline
\end{tabular}

Grafik 1. Rekapitulasi Ketuntasan Belajar Siswa 


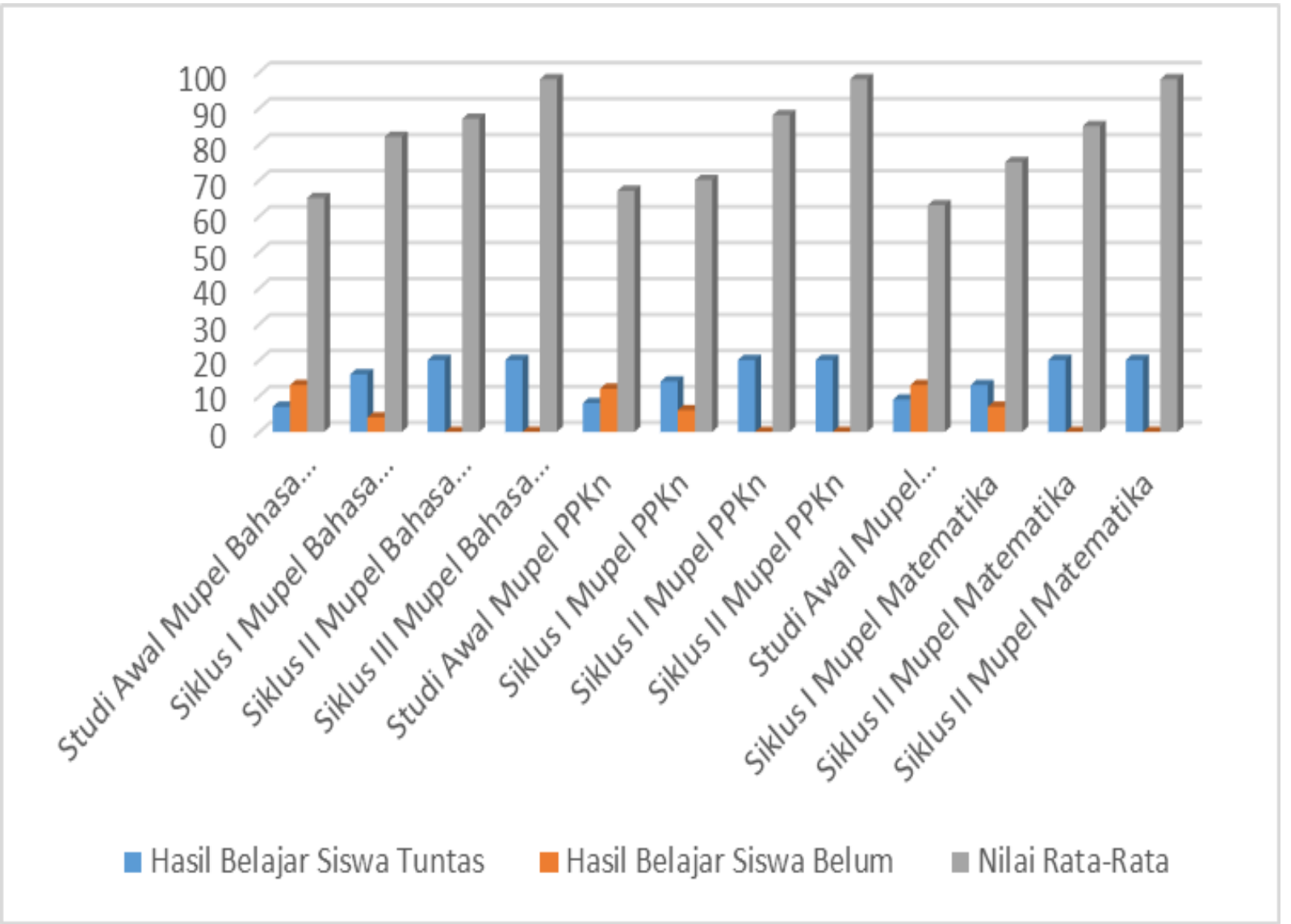

Hasil penelitian diperoleh ketuntasan belajar 100 persen dengan rincian sebagai berikut :

Bahasa Indonesia

a. Pada studi awal, siswa yang tuntas belajar sebanyak 7 siswa dari 20 siswa (35\%) dengan nilai rata-rata 65.

b. Pada siklus I, siswa yang tuntas belajar sebanyak 16 siswa dari 20 siswa $(80 \%)$ dengan nilai rata-rata 82 .

c. Pada siklus II, siswa yang tuntas belajar sebanyak 20 siswa dari 20 siswa (100\%) dengan nilai rata-rata 87.

d. Pada siklus III, siswa yang tuntas belajar sebanyak 20 siswa dari 20 siswa (100\%) dengan nilai rata-rata 98.

PPKn

a. Pada studi awal, siswa yang tuntas belajar sebanyak 8 siswa dari 20 siswa (40\%) dengan nilai rata-rata 67.

b. Pada siklus I, siswa yang tuntas belajar sebanyak 14 siswa dari 20 siswa $(70 \%)$ dengan nilai rata-rata 80 .

c. Pada siklus II, siswa yang tuntas belajar sebanyak 20 siswa dari 20 siswa (100\%) dengan nilai rata-rata 88 .

d. Pada siklus II, siswa yang tuntas belajar sebanyak 20 siswa dari 20 siswa (100\%) dengan nilai rata-rata 98.

Matematika

a. Pada studi awal, siswa yang tuntas belajar sebanyak 9 siswa dari 20 siswa (45\%) dengan nilai rata-rata 63.

b. Pada siklus I, siswa yang tuntas belajar sebanyak 13 siswa dari 20 siswa (65\%) dengan nilai rata-rata 75 . 
c. Pada siklus II, siswa yang tuntas belajar sebanyak 20 siswa dari 20 siswa (100\%) dengan nilai rata-rata 85.

d. Pada siklus III, siswa yang tuntas belajar sebanyak 20 siswa dari 20 siswa (100\%) dengan nilai rata-rata 85.

Sedangkan siswa yang belum tuntas dalam belajar adalah sebagai berikut :

Bahasa Indonesia :

a. Pada studi awal, siswa yang belum tuntas sebanyak 13 siswa dari 20 siswa (65\%).

b. Pada siklus I, siswa yang belum tuntas sebanyak 4 siswa dari 20 siswa (20\%).

c. Pada siklus II, siswa yang belum tuntas sebanyak 0 siswa dari 20 siswa $(0 \%)$.

d. Pada siklus III, siswa yang belum tuntas sebanyak 0 siswa dari 20 siswa ( $0 \%)$. PPKn

a. Pada studi awal, siswa yang belum tuntas sebanyak 12 siswa dari 20 siswa (60\%).

b. Pada siklus I, siswa yang belum tuntas sebanyak 6 siswa dari 20 siswa (30\%).

c. Pada siklus II, siswa yang belum tuntas sebanyak 0 siswa dari 20 siswa $(0 \%)$.

d. Pada siklus III, siswa yang belum tuntas sebanyak 0 siswa dari 20 siswa (0\%).

Matematika

a. Pada studi awal, siswa yang belum tuntas sebanyak 13 siswa dari 20 siswa (65\%).

b. Pada siklus I, siswa yang belum tuntas sebanyak 7 siswa dari 20 siswa (35\%).

c. Pada siklus II, siswa yang belum tuntas sebanyak 0 siswa dari 20 siswa (0\%).

d. Pada siklus III, siswa yang belum tuntas sebanyak 0 siswa dari 20 siswa (0\%).

\section{SIMPULAN}

Kesimpulan yang dapat diambil dari temuan dan hasil yang diperoleh yaitu banyak hal yang menarik dalam penelitian ini dan banyak pembelajaran di dalamnya dimana yang utama yaitu dengan menggunakan media konkret dalam pembelajaran dapat meningkatkan hasil belajar siswa yang signifikan yaitu dengan ketuntasan belajar dan hasil belajar yang signifikan yaitu mencapai $100 \%$ dengan nilai rata-rata 98 pada siklus III.

\section{DAFTAR PUSTAKA}

Arief Sadiman, dkk., Media Pendidikan Pengertian, Pengembangan, \& Pemanfaatannya. (Jakarta: PT Raja Grafindo Persada, 2010).

Arikunto, Suharsimi dkk. 2014. Penelitian Tindakan Kelas. Cet. XII; Jakarta: Bumi Aksara.

Djamarah, Syaiful Bahri dan Aswan Zain. 2012. Strategi Belajar Mengajar. Cet. II; Jakarta: Asdi Mahasatya.

Hamzah, Ali dan Muhlisrarini. 2014. Perencanaan dan Strategi Pembelajaran Matematika. Cet. l; Jakarta: RajaGrafindo Persada

Khomsoh, R. (2013). Penggunaan Media Puzzle Untuk Meningkatkan Hasil Belajar Siswa Dalam Pembelajaran Sosial di Sekolah Dasar. Jurnal Penelitian Pendidikan Guru Sekolah Dasar, 1(2), 1-11.

Maharani, Ervina. 2014. Panduan Sukses Menulis Penelitian Tindakan Kelas Yang Simpel, Cepat, Dan Memikat. Cet. l; Yogyakarta: Parasmu.

Purwanto. 2014. Evaluasi Hasil Belajar. Yogyakarta: Pustaka Belajar.

Soleha. (2016). Penerapan Model Pembelajaran Kooperatif Tipe Make A Match Untuk Meningkatkan Hasil Belajar Matematika Siswa Kelas IV SD Negeri Gayau Sakti Tahun Pelajaran 2014/2015. Jurnal Pendidikan, 5(1), 68-74.

Susanto, Ahmad. 2014. Teori Belajar \& Pembelajaran di Sekolah Dasar. Cet. I; Jakarta: Kencana. 